\title{
PENGUKURAN KINERJA PT. PLN (Persero) WILAYAH MALUKU DAN MALUKU UTARA MENGGUNAKAN MALCOLM BALDRIGE
}

\author{
B. J. Camerling \\ Program Studi Teknik Industri, Fakultas Teknik Universitas Pattimura, Ambon \\ Mirsan \\ PLN Wilayah Maluku dan Maluku Utara, Ambon
}

\begin{abstract}
ABSTRAK
Perkembangan teknologi dan industri di dunia dewasa ini sangat pesat. Pada suatu perusahaan, pengukuran kinerja sangat dimanfaatkan untuk membantu mengevaluasi tingkat pencapaian kinerja suatu perusahaan. Wawasan dari mahasiswa tentang dunia kerja yang berkaitan dengan industrialisasi sangat diperlukan sehubungan dengan kondisi objektif indonesia yang merupakan negara berkembang dan memerlukan pembangunan yang lebih sempurna dalam segala bidang. Universitas Pattimura Ambon sebagai sebuah institusi (Perguruan Tinggi) berupaya untuk memberikan pengetahuan kepada mahasiswanya bagaimana kinerja suatu perusahaan dapat tercapai dan mahasiswa secara langsung dapat menerapkan ilmu yang telah di dapatkan selama dibangku kuliah. Wilayah kerja PT.PLN (Persero) Wilayah Maluku dan Maluku Utara Meliputi Area Ambon, Area Tual, Area Masohi, Area Ternate, dan Area Sofifi. PLN Wilayah Maluku dan Maluku Utara menerima pelaporan kondisi Kinerja unit-unit yang akan dievaluasi baik tiap triwulan maupun semester. Pengukuran Kinerja hanya dilakukan dengan mengumpulkan kinerja masing-masing area secara manual. Berangkat dari masalah tersebut, maka penelitian ini dilakukan dengan tujuan Mengukur Kinerja Perusahaan dengan menggunakan Malcom Badrige, sehingga kinerja perusahaan dapat diukur, dianalisa dan perbaikan kinerja perusahaan dapat tercapai.
\end{abstract}

Kata Kunci : Malcom Badrige, Kinerja Perusaahaan, Perbaikan Kinerja

\begin{abstract}
The development of technology and industry in the world today is very rapid. In a company, performance measurement is used to help evaluate the level of achievement of a company's performance. Insights from students about the world of work related to industrialization are needed in connection with the objective conditions of Indonesia which is a developing country and requires more perfect development in all fields. Ambon Pattimura University as an institution (Higher Education) seeks to provide knowledge to its students how the performance of a company can be achieved and students can directly apply the knowledge they have gained during their studies. The working area of PT. PLN (Persero) Maluku and North Maluku Region include Ambon Area, Tual Area, Masohi Area, Ternate Area, and Sofifi Area. PLN Maluku Maluku and North Maluku receive reporting on the condition of the performance of the units that will be evaluated both quarterly and semester. Performance measurement is only done by collecting the performance of each area manually. Departing from these problems, this research was conducted with the aim of Measuring Company Performance by using Malcom Badrige, so that company performance can be measured, analyzed and improvements in company performance can be achieved.
\end{abstract}

Kata Kunci : Malcom Baldrige, Company Performance, performance improvement.

\section{PENDAHULUAN}

PLN Wilayah Maluku \&Maluku Utara menyeleksi dan mengumpulkan data dan informasi dari Area dan Sektor melalui Laporan Data Pengusahaan yang diselaraskan dan diintegrasikan sebagai materi review kinerja unit-unit antara Tim Kinerja Maluku \&Maluku Utara dengan Tim Kinerja Area dan Sektor. Review antara Tim Kinerja PLN Maluku \& Maluku Utara dengan Tim Kinerja Area dan Sektor menghasilkan Laporan Realisasi Kinerja yang disepakati antara Manajemen Area dan Sektor dengan Tim Kinerja Maluku \&Maluku Utara untuk dilaporkan ke Manajemen Wilayah Maluku \&Maluku Utara.

Indikator kinerja PLN Maluku \&Maluku Utara meliputi 6 (enam) perspektif yaitu Pelanggan, Produk dan Layanan, Proses Bisnis Internal, SDM, Keuangan dan Pasar dan Kepemimpinan. PLN Maluku \&Maluku Utara menggunakan SILM sebagai metode untuk mengukur kinerja perusahaan, 
diharapkan dengan metode ini kinerja organisasi dari berbagai perspektif dapat diukur dan dimonitor.Hal tersebut diatur melalui SK DIR Nomor 181.K/DIR/2013 tentang Manajemen Kinerja KorporasiDan Penilaian Kinerja Organisasi 2013. Untuk dapat mendorong perbaikan perusahaan secara terusmenerus, setiap tahun dilakukan penyempurnaan atas indikator kinerja PLN Wilayah Maluku \&Maluku Utara disesuaikan dengan target utama PLN secara korporat yang tertuang dalam Kontrak Kinerja Manajemen dan target keuangan serta operasional dalam RKAP tahun yang bersangkutan. Kontrak kinerja manajemen lalu diturunkan ke masing-masing bidang dan dibuat kontrak manajemen antara PLN Wilayah Maluku \&Maluku Utara dengan Area maupun sektor.Realisasi kinerja di-review Tim Kinerja PLN MMU melalui laporan Data Pengusahaan Area dan Sektor yang dilaporkan ke Wilayah tiap bulan (tanggal 1-10), dan dimutakhirkan melalui SILM paling lambat tanggal 15 setiap bulannya dan pemantauan Kontrak Kinerja dengan Area dan Sektor pertriwulan. Dan di-review manajemen melalui :

- Rapim tiap bulan yang diikuti GM \& Manajer Bidang.

- Tinjauan Kinerja yang diikuti oleh Pemimpin Senior diadakan setiap triwulan.

PLN Wilayah Maluku \& Maluku Utara menggunakan data dan informasi untuk mendukung keputusan, perbaikan yang berkelanjutan dan inovasi. Untuk mendukung operasional dan pengambilan keputusan strategis, PLN Wilayah Maluku \& Maluku Utara menggunakan pembanding data dan informasi internal dari progress periode sebelumnya, hal ini sudah cukup menjamin arah bisnis akan semakin baik secara berkesinambungan. Didalam RKAP (Rencana Kerja Anggaran Perusahaa) telah dirumuskan/diuraikan program kerja untuk mencapai sasaran dan target. Untuk memastikan target akan tercapai atau melihat kondisi target sulit dicapai ditempuh melalui inovasi. Proses benchmark dilakukan oleh PS dengan mengikuti rapat pencapaian kinerja bidang terkait dimaksudkan sebagai upaya memperoleh data pembanding yang jika mungkin digunakan sebagai pendorong untuk melakukan perbaikan dan inovasi.

Tujuan dari penelitian ini adalah untuk mengukur kinerja PT. PLN (Persero) Wilayah Maluku dan Maluku Utara serta memberikan rekomendasi pengukuran kinerja dengan menggunakan aplikasi Macom Balridge.

\section{LANDASAN TEORI \\ Defenisi Pengukuran Kinerja}

Pengukuran kinerja dalam bahasa inggris disebut Performance Apprisial Atau Performance Evaluation. Dua defenisi klasik tentang penilaian kerja karyawan dibawah ini diajukan oleh Dr. Joseph M. Putty dalam bukunya “A Manager's Primer An Performance Apprisia" (Singapore Institute Of Personnel Management, 1987)

Roger Belows, dalam psichology of personnal in bussines industry, prentice hall, new jersey 1961, p 370 : "a periodical evaluation on the value of an individual employee for hislher organization conducted by hislher superior or by someone in a position to evaluate hislher performance"(Suatu penilaian periodik atas nilai seorang individu karyawan bagi organisasinya. Dilakukan oleh atasannya atau seseorang yang berada dalam posisi untuk mengamati atau menilai prestasi kerjanya).

Dale S. Beach, The Management Of People at Work, Mac Milan New York, 1970 p 257: “A systematic evaluation on an individual employee regarding hislher performance on hislher job potentioals for development"(sebuah penilaian sistematis atas individu karyawan mengenai prestasinya dalam pekerjaannya dan potensinya untuk pengembangan).

Bernardin \& Russel 1993: 379 : "A way of measuring the contribution of individuals to their organization". (Cara mengukur kontribusi individu (karyawan) kepada organisasi tempat mereka bekerja).

Cascio (1992: 267) ; “... is the systematic description of the job relevan strengths and weaknesses of an individual or group”. (Sebuah gambaran/deskripsi sistematis tentang kekuatan dan kelemahan yang terkait dengan pekerjaan dari seseorang atau satu kelompok).

Dari beberapa pengertian diatas Pengukuran kinerja didefenisikan secara umum yaitu: proses di mana organisasi menetapkan parameter hasil untuk dicapai oleh program, investasi, dan akusisi yang dilakukan. Proses pengukuran kinerja seringkali membutuhkan penggunaan bukti statistik untuk menentukan tingkat kemajuan suatu organisasi dalam meraih tujuannya. Tujuan mendasar di balik dilakukannya pengukuran adalah untuk meningkatkan kinerja secara umum.

Pengukuran kinerja dapat memberikan manfaat sebagai berikut:

1. Untuk mengevaluasi

2. Untuk mengendalikan

3. Untuk menganggarkan

4. Untuk memotivasi 
5. Untuk merayakan

6. Untuk bias belajar

7. Untuk mengembangkan.

Pengukuran kinerja dilakukan dengan mengacu pada prinsip-prinsip sebagai berikut:

1. Seluruh aktivitas kerja yang signifikan harus diukur

2. Pekerjaan yang tidak diukur atau dinilai tidak dapat dikelola karena darinya tidak ada informasi yang bersifat obyektif untuk menentukan nilainya

3. Kerja yang tak diukur selayaknya diminimalisir atau bahkan ditiadakan

4. Keluaran kinerja yang diharapkan harus ditetapkan untuk seluruh kerja yang diukur

5. Hasil keluaran menyediakan dasar untuk menetapkan akuntabilitas hasil alih-alih sekedar mengetahui tingkat usaha

6. Mendefinisikan kinerja dalam artian hasil kerja semacam apa yang diinginkan adalah cara manajer dan pengawas untuk membuat penugasan kerja dari mereka menjadi operasional

7. Pelaporan kinerja dan analisis variansi harus dilakukan secara kerap

8. Pelaporan yang kerap memungkinkan adanya tindakan korektif yang segera dan tepat waktu

9. Tindakan korektif yang tepat waktu begitu dibutuhkan untuk manajemen kendali yang efektif

\section{Malcom Baldrige}

Menurut George salah satu kerangka kinerja untuk mencapai mutu tinggi adalah Kriteria The Malcolm Baldrige National Quality Award (MBNQA) atau yang dikenal dengan Malcolm Baldrige. Sebagai alat penilaian mandiri (selft assessment), kriteria MBNQA membantu mengidentifikasi kekuatankekuatan perusahaan, mencari peluang-peluang perusahaan dan mencari peluang bagi perbaikan proses dan hasil yang berdampak kepada stakeholder, pelanggan, karyawan, pemilik (owner), pemasok (supplier), serta masyarakat. Kriteria MBNQA juga membantu dalam hal mengatur sumber daya, antara lain: memperbaiki komunikasi, produktivitas, efektivitas, serta mencapai tujuan-tujuan organisasi.

Kriteria Baldrige sebagai suatu kriteria untuk keunggulan kinerja yang digunakan, telah diadopsi oleh puluhan negara di dunia menjadi National Quality Award negaranya masing-masing . Metode Malcolm baldrige merupakan suatu sistem perspektif sebagai pedoman strategi cara pengelolaan perusahaan melalui proses-proses kunci guna menuju kinerja yang unggul, yang mengetengahkan keselarasan sistem yang terintegrasi dari ketujuh kategori tersebut dan adanya saling keterkaitan antar kategori kriteria dengan kepemimpinan sebagai motor penggeraknya. Sedangkan peran kepemimpinan sangat ditekankan, hal ini ditunjukkan dengan pembobotan nilainya diantara 6 kategori proses, diberikan nilai tertinggi yaitu dengan nilai maksimum 120.

Kepemimpinan merupakan kekuatan pendorong bagi sistem di perusahaan yang menciptakan hasil. Dengan berdasarkan bahwa pedoman tentang pengukuran kinerja dengan metode Malcolm baldrige masing-masing komponen kategori saling memiliki keterkaitan dan kepemimpinan adalah menjadi driver. Metode ini memberikan pedoman bahwa untuk melakukan proses pengukuran kinerja tersebut, penilaian dilakukan terhadap area to address yakni komponen-komponen yang menjadi perhatian untuk mengukur pelaksanaan kinerja organisasi pada ketujuh kategori kriteria dimaksud, yaitu 5 area to address pada kategori Kepemimpinan dan 27 area to address pada 6 kategori kriteria lainnya.

Gambar dibawah ini menunjukkan tujuh kriteria/ kategori MBNQA yang akan dipergunakan untuk menilai kinerja.

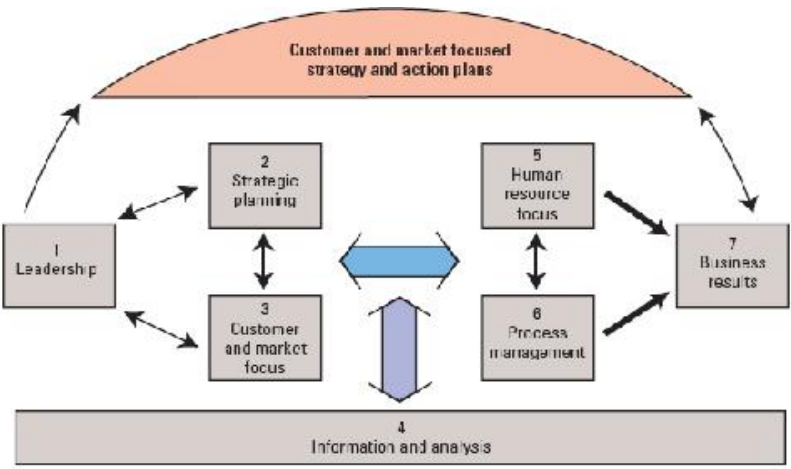

Kriteria Malcolm Baldrige 
Penilaian kinerja dengan metode ini berbasis pada perbaikan kinerja yang berkelanjutan yang di tunjukkan pada pedoman jenjang predikat dan skor kinerja ditunjukkan pada table berikut ini.

Jenjang Predikat dan Nilai Skor Kinerja Malcolm Baldrige

\begin{tabular}{|c|c|c|}
\hline Jenjang predikat & Skor & Level \\
\hline EarlyDevelopment & $0-275$ & \multirow{2}{*}{ Poor } \\
\hline Early Result & $276-375$ & \\
\hline EarlyImprovement & $376-475$ & \multirow{2}{*}{ Average } \\
\hline Good Peformance & $476-575$ & \\
\hline $\begin{array}{c}\text { EmergingIndustry } \\
\text { Leader }\end{array}$ & $576-675$ & \\
\hline Industry Leader & $676-775$ & \multirow{2}{*}{ Exellent } \\
\hline BenchamarkLeader & $776-875$ & \\
\hline World Leader & 876 & \\
\hline
\end{tabular}

Kaitan antar 7 aspek tersebut dapat dilihat pada tabel di atas ini. Tabel tersebut menggambarkan bagaimana aspek-aspek atau kriteria-kriteria tersebut berkaitan dan berproses membentuk profi 1 organisasi. Kriteria-kriteria tersebut memiliki bobot masing-masing dengan total nilai 1000 points. Seluruh kriteria tersebut di analisa dengan bentuk pertanyaan-pertanyaan untuk masing-masing kategori sebagai berikut: Kepemimpinan (120 points), Perencanaan Strategis (85 points), Fokus Terhadap pelanggan Yang Dilayani (85 points), Pengukuran, Analisa Dan Pengetahuan Manajemen (90 points), Fokus Terhadap Sumber Daya Manusia (85 points), Manajemen Proses (85 points), Hasil Yang Diperoleh (450 points).

\section{Pembobotan Dengan Analytic Network Process (ANP)}

Algoritma perhitungan pembobotan yang di lakukan dimulai dari data dengan bentuk pairwaise comparison sampai dihasilkan bobot tiap indikator kinerjanya. Strategi objektif yang memiliki hanya satu KPI, secara otomatis nilai bobot strategi objektifnya sama dengan KPInya. Sedangkan strategi objektif yang memiliki lebih dari satu KPI, maka bobot strategi objektifnya diakomodasikan pada KPI KPI yang di milikinya. Keterkaitan yang ada akan menjadi dasar penyusunan formasi supermatriknya. Untuk memperoleh bobot tiap strategi objektif dan KPI, terlebih dahulu supermatrik yang berbobot di lakukan pemangkatan dari nilai supermatrik yang terbobotnya sehingga di hasilkan nilai bobot yang stabil.Nilai bobot di nyatakan stabil bila dominasi antar elemen telah terdistribusi pada keseluruhan matrik. Matrik yang memiliki bobot yang stabil disebut dengan limiting matrix.

Data yang digunakan adalah hasil kuesioner dengan bentuk perbandingan berpasangan (pairwise comparison) yang di sebarkan kepada pihak manajemen PT.PLN (Persero) Wilayah Maluku dan Maluku Utara yang berkompeten.

\section{Analisis SWOT}

Analisa SWOT adalah suatu metoda penyusunan strategi perusahaan atau organisasi yang bersifat satu unit bisnis tunggal, dengan menggambarkan kondisi dan mengevaluasi suatu masalah, proyek atau konsep bisnis yang berdasarkan faktor internal (dalam) dan faktor eksternal (luar) yaitu Strengths, Weakness, Opportunities dan Threats. Metode ini paling sering digunakan dalam metode evaluasi bisnis untuk mencari strategi yang akan dilakukan. Analisis SWOT hanya menggambarkan situasi yang terjadi bukan sebagai pemecah masalah. Salah satu model perencanaan strategis adalah analisis SWOT (Strength, Weaknesses, Opportunities dan Threats). S dan W mengidentifikasikan kekuatan dan kelemahan internal perusahaan dalam hal ini berkaitan dengan fungsi manajemen (perencanaan, pengorganisasian, pengarahan, pemberian motivasi dan pengendalian). Model analisis SWOT pada variable $\mathrm{S}$ dan $\mathrm{W}$ mengidentifikasi kekuatan dan kelemahan pada fungsi bisnis yaitu : merancang pemasaran dan produk; produksi dan penawaran; sumber daya manusia; dan keuangan. Sedangkan variabel $\mathrm{O}$ dan $\mathrm{T}$ merupakan analisis eksternal - berupa peluang dan ancaman yang meliputi aspek : sosial, teknologi, ekonomi, politik, hukum, lingkungan, demografi dan pesaing. Dalam analisis matrix SWOT diterapkan sistem "skoring" untuk unsur-unsur yang dianggap penting."Bobot" menunjukkan kepentingan relatif dari sub-elemen dalam komponen SWOT pada setiap perusahaan dari waktu ke waktu. Untuk perusahaan baru, aspek $\mathbf{S}$ dan $\mathrm{W}$ - nya tentu berbeda dengan perusahaan yang sudah berdiri, 
khususnya di aspek kinerja. Di sini analisis harus mencatat berbagai macam perbedaan yang ada pada laporan tersebut.

\section{Survey, Pengumpulan Data Dan Informasi}

Tahap Studi Lapangan atau Survey dilakukan dengan tujuan untuk mengetahui dan melihat secara langsung dan lebih mendetail permasalahan yang akan diteliti, sehingga diperoleh data-data atau informasi yang diperlukan. Pada tahap ini dilakukan dengan cara :

Interview yaitu suatu cara mendapatkan data melalui wawancara langsung dengan orang yang berhubungan langsung dengan masalah. Pembuatan kuisioner bertujuan untuk mendapatkan data kualitatif yang akan di gunakan untuk mendapatkan bobot dari masing-masing sub kriteria. Kuisioner ini akan di sebarkan ke respondent di antaranya adalah karyawan PT. PLN (Perero) Wilayah Maluku dan Maluku Utara.

Observasi yaitu cara pengumpulan data yang dilakukan dengan mengadakan peninjauan langsung dengan objek yang diteliti. Perancangan sistem pada bagian ini meliputi garis besar perancangan sistem informasi pengukuran kinerja pada PT. PLN (Persero). Yang meliputi 5 tahapan, tahap yang pertama adalah penyebaran kuisioner, tahap ke dua menguji validitas, reliabilitas, dan kecukupan data, tahap ke tiga adalah proses pembobotan dengan ANP, tahap ke empat menghitung score Sub Kriteria dengan Malcolm Baldrige, dan tahap yang ke lima adalah merancang analisis SWOT untuk menyimpulkan hasil

pengukuran. Tahap ini terdiri dari : Menentukan Sub Kriteria ditunjukkan pada table berikut ini

Sub Kriteria Penilaian Kinerja Berdasarkan Kriteria Malcolm Baldrige

\begin{tabular}{|c|c|c|c|c|c|}
\hline $\begin{array}{c}\text { Kode } \\
\text { Kriteria }\end{array}$ & Kriteria Umum & $\begin{array}{c}\text { Kode Sub } \\
\text { Kriteria }\end{array}$ & Sub Kriteria & Point & Nilai \\
\hline \multirow[t]{2}{*}{ A } & \multirow[t]{2}{*}{ Kepemimpinan } & A1 & Kepemimpinan Senior & 70 & \multirow[t]{2}{*}{120} \\
\hline & & $\mathrm{A} 2$ & Kepemimpinan dan Tanggung Jawab sosial. & 50 & \\
\hline \multirow[t]{2}{*}{ B } & \multirow[t]{2}{*}{ Perencanaan Strategis } & B1 & Pengembangan Strategi & 40 & \multirow[t]{2}{*}{85} \\
\hline & & B2 & Penyebarluasan Strategi & 45 & \\
\hline \multirow[t]{2}{*}{$\mathrm{C}$} & \multirow[t]{2}{*}{$\begin{array}{ll}\text { Fokus } & \text { terhadap } \\
\text { Pelanggan } & \end{array}$} & $\mathrm{C} 1$ & $\begin{array}{l}\text { Pengetahuan pelanggan, pelanggan lain, dan } \\
\text { pasar. }\end{array}$ & 40 & \multirow[t]{2}{*}{85} \\
\hline & & $\mathrm{C} 2$ & $\begin{array}{l}\text { Kepuasan dan relasi pelanggan serta } \\
\text { pelanggan lainya }\end{array}$ & 45 & \\
\hline \multirow[t]{2}{*}{$\mathrm{D}$} & \multirow{2}{*}{$\begin{array}{l}\text { Pengukuran, Analisa } \\
\text { dan Pengetahuan } \\
\text { Manajemen }\end{array}$} & D1 & $\begin{array}{l}\text { Pengukuran, Analisa dan Peningkatan } \\
\text { Kinerja Organisasi }\end{array}$ & 45 & \multirow[t]{2}{*}{90} \\
\hline & & D2 & Informasi dan manajemen pengetahuan & 45 & \\
\hline \multirow[t]{3}{*}{$\mathrm{E}$} & \multirow{3}{*}{$\begin{array}{l}\text { Fokus pada Sumber } \\
\text { Daya Manusia }\end{array}$} & E1 & Sistem kerja & 45 & \multirow{3}{*}{85} \\
\hline & & E2 & Pembelajaran dan motivasi staf & 20 & \\
\hline & & E3 & Kesejahteraan dan kepuasan staf & 20 & \\
\hline \multirow[t]{2}{*}{$\mathrm{F}$} & \multirow[t]{2}{*}{ Proses Manajemen } & F1 & Proses pelayanan Produk & 35 & \multirow[t]{2}{*}{85} \\
\hline & & F2 & $\begin{array}{l}\text { Proses pendukung dan perencanaan } \\
\text { operasional }\end{array}$ & 50 & \\
\hline \multirow[t]{6}{*}{ G } & \multirow[t]{6}{*}{ Hasil yang di peroleh } & G1 & $\begin{array}{l}\text { Hasil pelayanan Produk dan hasil } \\
\text { penyediaan pelayanan }\end{array}$ & 100 & \multirow{6}{*}{450} \\
\hline & & G2 & Hasil focus pelanggan dan pelanggan lain & 70 & \\
\hline & & G3 & Hasil keuangan dan pasar & 70 & \\
\hline & & G4 & Hasil staf dan system kerja & 70 & \\
\hline & & G5 & Hasil keefektifan organisasi & 70 & \\
\hline & & G6 & $\begin{array}{l}\text { Hasil Kepemimpinan dan tanggung jawab } \\
\text { social }\end{array}$ & 70 & \\
\hline \multicolumn{5}{|c|}{ Total Nilai } & 1000 \\
\hline
\end{tabular}

\section{METODE PENELITIAN}

\section{Variabel dan Definisi Operasional}

Variabel keputusan dapat dinotasikan dengan lambang X. Yang termasuk dalam indikator variabel keputusan dalam penilitian adalah sebagai berikut :

a. Prespektif pelanggan $\left(\mathrm{X}_{1}\right)$

b. Prespektif efektifitas produk dan proses $\left(\mathrm{X}_{2}\right)$

c. Prespektif keuangan dan pasar $\left(\mathrm{X}_{3}\right)$

d. Prespektif kepemimpinan $\left(\mathrm{X}_{4}\right)$

e. Prespektif program unggulan $\left(\mathrm{X}_{5}\right)$ 
Variabel keputusan merupakan suatu indikator untuk mencapai variabel tujuan. Yang mana variabel tujuan adalah untuk mengukur kinerja perusahaan PT. PLN (Persero) Wilayah Maluku Dan Maluku Utara.

\section{Metode Analisa Data}

Analisis data adalah proses pengimpunan atau pengumpulan, pemodelan dan transformasi data dengan tujuan untuk menyoroti dan memperoleh informasi yang bermanfaat, memberikan saran, kesimpulan dan mendukung pembuatan keputusan. Analisis data pada penelitian ini adalah data yang diperoleh diolah dan dianalisis berpedoman pada MBCfPE 2013.

\section{HASIL DAN PEMBAHASAN}

\section{Hasil Produk dan Proses yang Fokus Kepada Pelanggan}

Produk Utama dari PLN Wilayah Maluku \& Maluku Utara adalah Pasokan Tenaga Listrik yang disalurkan kepada masyarakat di Provinsi Maluku \& Maluku Utara. Indikator utama dari produk ini dapat di lihat melalui trend Produksi Tenaga Listrik dan kWh Tenaga Listrik yang terjual di Masyarakat. Tenaga Listrik yang diproduksi maupun yang dijual oleh PLN MMU mengalami trend peningkatan.

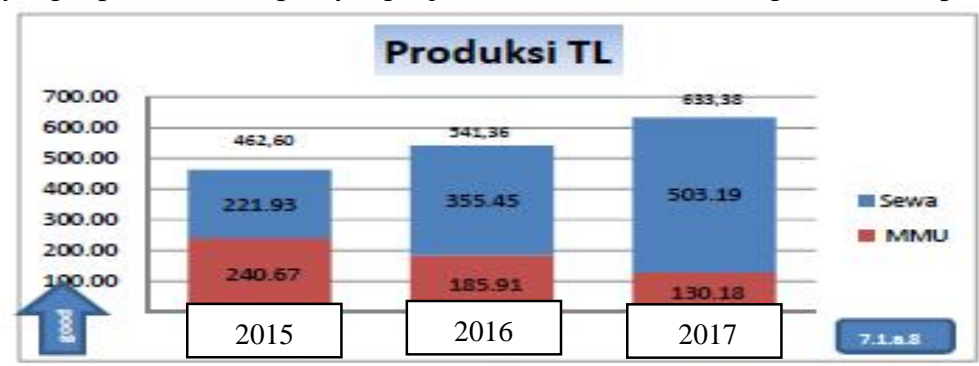

Produksi Tenaga Listrik

Pengukuran kinerja dari porduk dan proses utama dapat dilihat dari indikator SAIDI dan SAIFI, indikator ini mengukur keandalan pasokan Tenaga Listrik PLN MMU baik dari sisi jumlah kali padam (SAIFI) maupun dari sisi berapa lama emadaman terjadi (SAIDI). Pencapaian ke dua indikator ini mengalami peningkatan pada tahun 2017, trend ke dua indikator iniPengukuran kinerja dari porduk dan proses utama dapat dilihat dari indikator SAIDI dan SAIFI, indikator ini mengukur keandalan pasokan Tenaga Listrik PLN MMU baik dari sisi jumlah kali padam (SAIFI) maupun dari sisi berapa lama emadaman terjadi (SAIDI). Pencapaian ke dua indikator ini mengalami peningkatan pada tahun 2017, trend ke dua indikator ini. Dalam melaksanakan Proses Pelayanan langsung kepada masyarakat terhadap produk yang ditawarkan, PLN Wilayah Maluku \& Maluku Utara dalam tahun 2017 berhasil menjalankan proses bisnis tersebut dibawah dari standar yang ditetapkan untuk setiap segmen pasarnya.

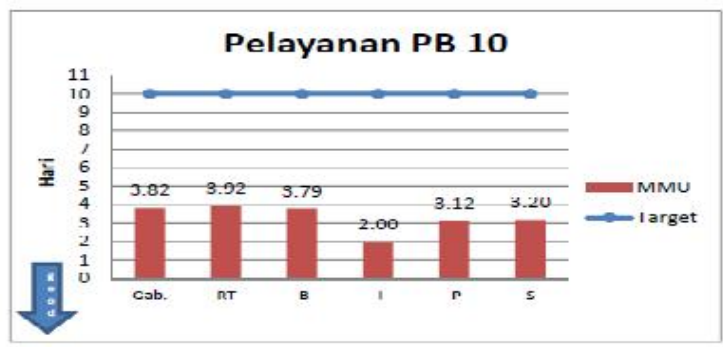

Grafik Pelayanan Pasang Baru 10

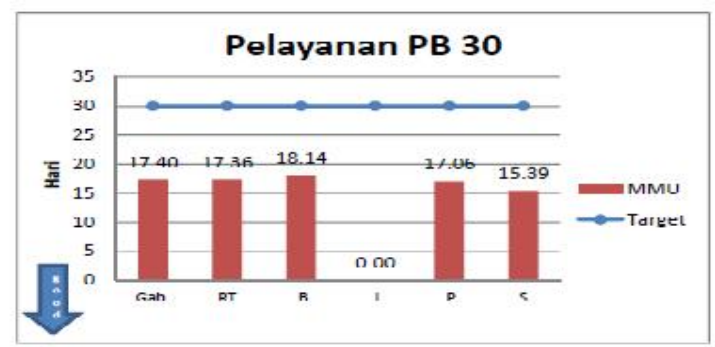

Grafik Pelayanan Pasang Baru 30 


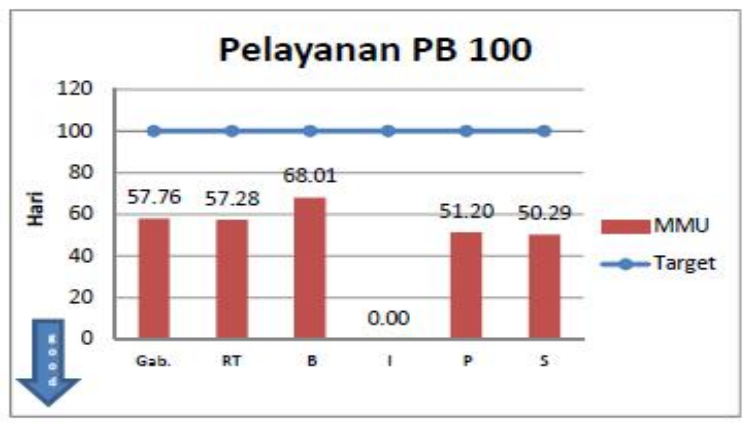

Grafik Pelayanan Pasang Baru 100

Feedback terhadap Produk dan Proses (Pelayanan) dari PLN Wilayah Maluku \& Maluku Utara oleh masyarakat dapat ditunjukan dalam Hasil Survey Kepuasan Pelanggan yang dilakukan oleh pihak ketiga dengan hasil.

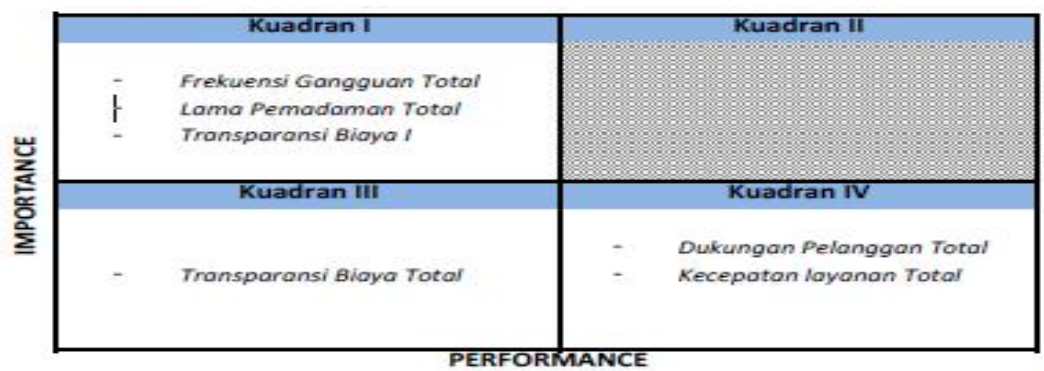

Survey Kepuasan Pelanggan tahun 2016

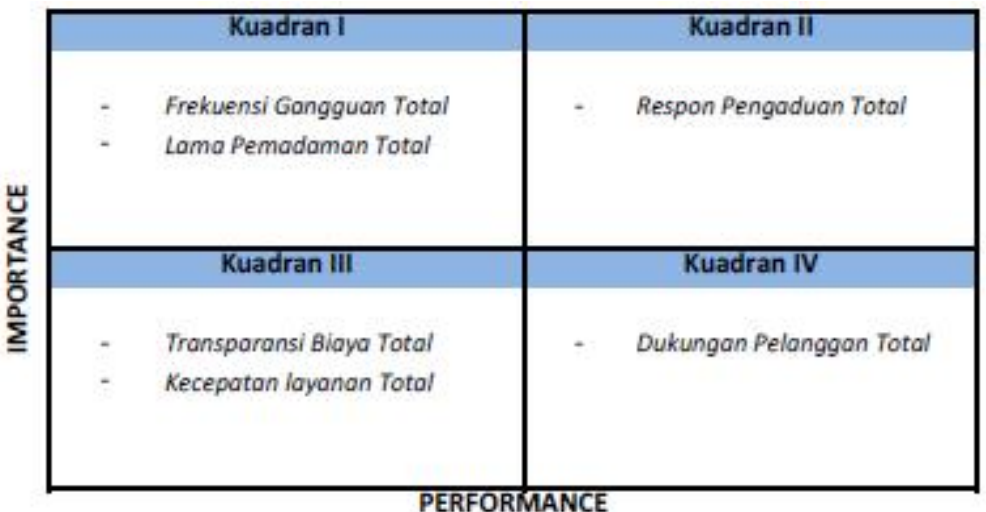

Survey Kepuasan Pelanggan Tahun 2017

Survey ini menunjukan bahwa Frekuensi Gangguan (SAIFI) dan Lama Pemadaman (SAIDI) seama 2 (dua) tahun terakhir ini masih harus menjadi perhatian bagi PLN Wilayah Maluku \& Maluku Utara karena berada dalam kuadran I. Untuk Proses yang lainya, seperti transparansi biaya,tingkat kecepatan layanan, respon terhadap pengaduan dan dukungan pelanggan mendapat respon yang cukup baik di mata masyarakat.

\section{Efektifitas Proses Kerja}

Indikator utama yang mengukur tingkat efektifitas Operasional PLN Wilayah Maluku \& Maluku Utara tercermin dalam beberapa indikator kinerja sebagai berikut :

\section{Bidang Pembangkitan :}

SdOF \& SOF Pembangkit

- $\quad$ Equivalent Forced Outage Ratio (EFOR) 
- $\quad$ Pertumbuhan Produksi Tenaga Listrik

- $\quad$ Sewa dan Beli Tenaga Listrik (GWh)

- Reserve Margin

- Bauran Energi

- $\quad$ Biaya Pokok Produksi

- $\quad$ SFC

- $\quad$ EAF

- Capacity Factor

- Load Factor

Beberapa indikator mempunyai trend yang positif dalam dua tahun terakhir (kecuali yang berhubungan dengan Produksi Tenaga listrik).

Bidang Distribusi :

- Jumlah Gangguan Penyulang

- Jumlah Gangguan Trafo

- Losses

Monitor secara terpusat untuk ke dua indikator ini dimulai pada tahun 2016 dengan hasil Indikator gangguan trafo, mempunyai trend yang positif dibanding tahun sebelumnya sedang Jumlah Gangguan Penyulang padatahun 2017 muncul sebesar 6,52 kali/100kms. Untuk indikator losses PLN MMU mengalami trend yang positif.

Bidang Administrasi \& Pelayanan Pelanggan :

- $\quad$ Rata-rata jumlah daftar tunggu

- $\quad$ Koreksi Rekening

- $\quad$ Penghematan E-Proc

- $\quad$ Penerapan PPOB

- $\quad$ Penyerapan Anggaran AI

Indikator Adm dan PP juga mengalami trend yang positif, kecuali pada indikator penyerapan AI.

Level dan Trend Inovasi pada PLN Wilayah Maluku \& Maluku Utara cukup berjalan dengan baik terbukti dengan adanya bebapra karya inovasi yang sudah lolos uji untuk di pertandingkan ke level nasional di setiap tahunya. Sedangkan untuk proses pemahaman bersama PLN Wilayah Maluku \& Maluku Utara juga melakukan Knowledge Sharing dan Knowledge Capturing.

Penurunan aktifitas terjadi pada tahun 2017, hal ini disebabkan karena adanya program Knowledge sharing secara on line sehingga memungkinkan terjadinya diskusi dan tukar pikiran tanpa harus bertatap muka. Untuk karya inovasi pada tahun 2017 juga mengalami penurunan, hal ini disebabkan karena beberapa karya inovasi tidak lulus uji dari pihak PLN Wilayah Maluku \& Maluku Utara untuk dapat melaju pada putaran tingkat nasional.

\section{Kesiapan Bencana}

PLN Wilayah Maluku \& Maluku Utara mempersiapkan jalur evakuasi dan peralatan antispatif (Seperti apar, baju kerja, safety aksesoris)terutama pada lokasi site (PLTD) yang dianggap sangat riskan terhadap keadaan majore force. Demikian pula dalam kantor pelayanan, PLN Wilayah Maluku \& Maluku Utara juga menyiapkan sarana keamanan dan jalur evakuasi.

Keamanan data dan back-up data juga tidak luput dari pantauan PLN Wilayah Maluku \& Maluku Utara Menggunakan UPS dengan daya besar di setiap server-server vital dan menyiapkan tempat back up untuk data-data tersebut untuk mengantisipasi kondisi darurat.

\section{Supply Chain Manajemen}

Indikator kinerja dari rantai supply dapat dilihat dari indikator prosentase keterlambatan pasokan dan prosentase denda terhadap kualitas pasokan. Pada tahun 2016 dan tahun 2017 terjadi hal -hal yang tidak dikehendaki dalam supply chain manajemen. Keterlambatan pasokan meningkat terutama pada unit sewa pembangkit demikian juga tingkat kualitas pasokan. Hal ini sangat mengganggu kinerja PLN Wilayah Maluku \& Maluku Utara, mengingat pada tahun 2016 dan 2017 proporsi produksi sangat dikendalikan oleh sewa pembangkit, jadi keterlambatan dan penurunan kualitas ini mempengaruhi produksi dan penjualan menjadi tidak optimal. Hal ini dapat dibuktikan dengan peningkatan SAIDI, SAIFI pada tahun 2016 dan 2017, demikian juga presepsi masyarakat ( hasil survey ) yang menunjukan bahwa Frekuensi pemadaman dan lama pemadaman berada dalam kuadran I yang artinya kedua hal ini perlu menjadi perhatian PLN MMU. 


\section{Hasil-hasil Fokus Pelanggan}

Pengukuran kepuasan dan ketidakpuasan pelanggan dilakukan melalui survei yang dilaksanakan oleh pihak intern/ Pusdiklat tahun 2015, sedangkan survei 2016 s.d 2017 dilakukan oleh lembaga independen / Perguruan Tinggi di Indonesia. Tujuan dilakukan survei adalah untuk mengetahui tingkat kualitas pelayanan pelanggan dipandang dari perspektif pelanggan, dan sekaligus memberikan penilaian terhadap kemampuan unit operasional dalam memelihara kualitas pelayanan yang diberikan kepada pelanggan dari hari ke hari. Hasil yang ditampilkan berdasarkan survei yang dilakukan terhadap pelanggan listrik yang dilayani oleh 5 PLN Distribusi dan 16 PLN Wilayah.

Indikator yang dipakai untuk mengukur kepuasan pelanggan adalah Kepuasan Pelanggan seperti adanya media yang mudah diakses dalam mendapatkan layanan pasang baru, mudahnya pelanggan dalam membayar rekening listrik secara PPOB, sedikitnya kesalahan dalam pencatatan meter, sedikitnya pemadaman dan singkatnya waktu dalam mengatasi gangguan. dalam hal ini menyangkut semua aspek pelanggan berdasarkan kelompok golongan tarif yang didalamnya terdiri dari pelanggan rumah tangga, sosial, bisnis, industri, TNI \& POLRI. Trend kepuasan pelanggan cenderung meningkat sejak tahun 2013 sampai tahun 2017.

Indikator ketidakpuasan pelanggan, menunjukkan trend kinerja yang sedikit cenderung turun (membaik). Pada tahun 2013 s/d 2015 tapi naik di tahun 2016 dan turun kembali di tahun 2017 indikator ini dihitung dengan metode mengurangkan angka maksimal dengan angka kepuasan pelanggan, dimana gap kepuasan merupakan ketidakpuasan. Indeks ketidakpuasan pelanggan yang naik pada tahun 2016 dikarenakan unit PLN Wilayah Maluku \& Maluku Utara kekurangan daya pembangkit dalam hal ini Sewa, banyaknya gangguan dan lamanya gangguan untuk bisa teratasi begitu juga susahnya mendapatkan pasang baru dan banyaknya kesalahan dalam pencatatan meter. Karena PLN tidak mempunyai pesaing, maka tidak ada pelanggan yang keluar/pindah menjadi pelanggan perusahaan lain. Keluarnya pelanggan setelah bongkar rampung disebabkan oleh bangkrut, kesulitan keuangan, tidak berpenghuni lagi, atau bangunan yang sudah tidak ada. Untuk membangun kerekatan dengan pelanggan, PLN selalu berupaya untuk memenuhi Tingkat Mutu Pelayanan. Beberapa indikator utama yang mencerminkan bagaimana kerekatan pelanggan semakin baik adalah kinerja kepuasan pelanggan, pertumbuhan jumlah pelanggan yang meningkat secara signifikan.

Berikut ini merupakan upaya PLN MMU untuk membangun kerekatan dengan pelanggan dengan membuat monitoring jumlah pelanggan yang melakukan komplain yang terjadi saat itu berikut juga membuat monitoring tindakan yang kita lakukan terhadap pelanggan yang komplain saat ini dan berapa pelanggan yang sudah dilakukan terakomodir komplainnya saat itu. Dalam APKT yang baru dilaksanakan pada tahun 2018 didapatkan data.

. Rasio Komplain Pelanggan dan TindakLanjut Sesuai Data APKT

\begin{tabular}{|l|l|c|c|c|}
\hline \multicolumn{1}{|c|}{ Indikator } & \multicolumn{1}{|c|}{ Formula } & Jan -18 & Feb-18 & $\begin{array}{c}\text { Mar- } \\
\mathbf{1 8}\end{array}$ \\
\hline $\begin{array}{l}\text { Rasio Jumlah } \\
\text { Komplain Pelanggan }\end{array}$ & $\begin{array}{l}\text { Jumlah Total Komplain } \\
\text { (pengaduan) / total } \\
\text { pelanggan }\end{array}$ & 2 & 8 & 14 \\
\hline $\begin{array}{l}\text { Rasio Tindak Lanjut } \\
\text { Komplain }\end{array}$ & $\begin{array}{l}\text { Jumlah komplain } \\
\text { selesai/total komplain }\end{array}$ & 2 & 8 & 14 \\
\hline
\end{tabular}

\section{Hasil-Hasil Fokus Tenaga Kerja}

A. Workforce Capability and Capacity

Hasil utama dari produk PLN Wilayah Maluku \& Maluku Utara adalah tenaga listrik. Penjualan energi listrik selalu mengalami kenaikan yang cukup signifikan dari tahun ke tahun. Jumlah pelanggan listrik PLN Wilayah Maluku \& Maluku Utara per pegawai naik dari Tahun 2015 sampai dengan Tahun 2017. Hal ini juga disebabkan oleh maksimalnya pengusahaan mesin sewa dari tahun ke tahun. Seiring dengan peningkatan pelanggan, energi listrik yang terjual juga mengalami peningkatan.

B. Workforce Climate

PLN Wilayah Maluku \& Maluku Utara juga berusaha meningkatkan pelayanan kepada pegawainya baik dalam hal kesehatan, keselamatan dan keamanan pegawai dalam bekerja sesuai dengan memperhatikan lingkungan tempat dimana pegawai tersebut bekerja. Dalam beberapa tahun terakhir juga PLN Wilayah Maluku \& Maluku Utara juga memfasilitasi pegawai melalui pembentukan COP untuk meningkatkan kinerja PLN MMU. Pegawai yang terlibat dalam COP dari Tahun 2015 sampai 2016 cenderung naik. Knowledge Sharing yang dilaksanakan PLN Wilayah Maluku \& Maluku Utara juga bertambah pertahunnya. 
C. Workforce Engagement

Berdasarkan hasil survey EES persepesi pegawai terhadap pengembangan tenaga kerja sudah dianggap baik, namun masih perlu dilakukan perbaikan. Demikian halnya juga dengan kepemimpinan.

D. Workforce Development

Dalam meningkatkan kompetensi pegawai, PLN Wilayah Maluku \& Maluku Utara juga mengikutsertakan pegawai dalam Training atau diklat.

\section{Hasil-Hasil Kepemimpinan, Tata Kelola dan Tanggung Jawab Sosial}

Komunikasi Pemimpin Senior dengan Tenaga Kerja maupun Pelanggan dilaksanakan oleh PLN Wilayah Maluku \& Maluku Utara dalam berbagai bentuk kegiatan seperti Kegiatan Coffe Morning,Knowledge Sharing, SBO, Kegiatan Keagamaan, melalui kegiatan Upacara HLN dan Acaraacara SBO dalam rangka HLN. Coffe Morning dan Knowledge Sharing yang dilaksanakan oleh PLN Wilayah Maluku \& Maluku Utara secara semi formal cukup mendapat respon positif dari tenaga kerja, terbukti adanya komunikasi dua arah antara pemimpin senior dengan tenaga kerja melalui masukanmasukan baik positif maupun negatif dari tenaga kerja kepada pemimpin senior dalam kegiatan tersebut yang diharapkan dapat membangun situasi kerja yang kondusif. Pencapaian kegiatan Knowledge Sharing antara PS dengan Tenaga Kerja. Sedangkan komunikasi secara formal juga dilakukan melalui kegiatan keagamaan, kegiatan keagaamaan diwujudkan dalam dua bentuk yaitu kegiatan pengajian setiap hari kamis siang yang dihadiri oleh tenaga kerja beragama Islam, dan persekutuan doa oleh tenaga kerja yang beragama Kristen/Khatolik setiap hari senin pagi. Pencapaian pelaksanaan kegiatan ini mencapai $90 \%$ dan efektif sebagai sarana komunikasi antara PS dan Tenaga Kerja. Untuk pencapaian akuntabilitas fiskal, PLN Wilayah Maluku \& Maluku Utara mempunyai trend yang positif dilihat dari kepatuhan pembayaran pajak (baik jumlah maupun batas waktu) dan respon terhadap hasil temuan BPK (dimulai tahun 2016).

Kepatuhan terhadap persyaratan hukum dan regulasi PLN Wilayah Maluku \& Maluku Utara ditunjukan melalui penanggulangan dampak negatif dan antisipasi kepedulian kepada masyarakat sekitar. Penanggulangan dampak negatif ditunjukan melalui indikator tingkat kebisingan, kandungan emisi, dan polutan limbah cair yang menjadi efek negatif dari pembangkit PLN MMU. Pencapaian indicator indikator tersebut. Ukuran utama perilaku etis dan kepercayaan stakeholder terhadap PS dan tata kelola organisasi PLN Wilayah Maluku \& Maluku Utara dapat dilihat melalui jumlah pelanggaran dari stakeholder baik dari sisi pelanggan, Mitra, Pemasok dan Pegawai PLN Wilayah Maluku \& Maluku Utara. pelanggaran baik dari sisi keterlambatan pasokan maupun kualitas pasokan. Pelanggaran oleh Tenaga Kerja terhadap PS dan Tata Kelola Organisasi PLN Wilayah Maluku \& Maluku Utara mempunyai pencapaian yang positif, dimana hanya terdapat 2 (dua) kali pelanggaran disiplin pegawai pada tahun 2017, dimana 1 (satu) pelanggaran adalah pelanggaran dalam bentuk sanksi SP 1 dan 1 (satu) pelanggaran dalam bentuk sanksi berupa teguran terltulis. Salah satu pemenuhan tanggung jawab sosietal dan dukungan organisasi terhadap komunitas utama terpenuhi melalui sarana PKBL. Dimana melalui program ini, PLN Wilayah Maluku \& Maluku Utara membagi dua bentuk kegiatan utama yaitu melaksanakan program Pasar Murah dimana PLN mendistribusikan dana kementrial (BL) dengan cara menjual paket sembako kepada masyarakat sekitar dan pelaksanaan penyerapan dananya $100 \%$. Selain Program Pasar Murah, PLN juga mempunyai program bantuan bencana yaitu kepada masyarakat Provinsi maluku pada waktu terjadi musibah banjir dan tanah longsor, dan kepada masyarakat di Maluku Utara pada waktu musibah Gunung Gamalama Meletus. Penyerapan terhadap bantuan ini juga hampir sempurna $(100 \%)$.

\section{Hasil Implementasi Strategi}

Indikator yang digunakan dalam implementasi strategi PLN Wilayah Maluku \& Maluku Utara meliputi : Indikator biaya pegawai per pelanggan, Efektivitas Biaya Pemeliharaan, Biaya Adm per Pelanggan, Penyediaan BBM \& Pelumas, dan lain-lain. PLN Wilayah Maluku \& Maluku Utara berhasil menurunkan tingkat biaya Cater, cetak rekening, dikarenakan adanya program AP2T dan pembacaan meter ACMT diserahkan kepada pihak ketiga.

\section{Hasil-Hasil Keuangan dan Pasar}

PLN Wilayah Maluku \& Maluku Utara secara mayoritas menggukan HSD sebagai bahan dasar produksi tenaga listrik. Pembebanan akan harga HSD pada nilai Ekonomis / Harga Industri ini menyebabkan semakin membesarnya biaya operasional. seiring dengan bertambahnya produksi tenaga listrik, dan berakibat pada peningkatan Rugi Tahunan.

Faktor-faktor atau indikator kinerja sebagai penunjang utama terbentuknya laba rugi pada PLN Wilayah Maluku \& Maluku Utara adalah 
sebagai berikut :

- $\quad$ Pendapatan Operasi dimana indikator ini menunjukan peningkatan di setiap tahun.

- Biaya Pemeliharaan dimana beban ini sedikit mengalami peningkatan di tahun 2016, tetapi PLN MMU berhasil mengendalikan dan menurunkan biaya ini pada tahun 2017

- $\quad$ Biaya Administrasi, pada indikator beban ini, PLN MMU mengalami peningkatan pada trend tahun terakhir (2017).

- Biaya Operasi melihat dari ukuran \& jumlah realisasinya maka indikator ini masih merupakan penentu dalam pencapaian laba/rugi PLN MMU, dan pada kondisi ini dimana beban operasi masih berada diatas pendapatan usaha PLN MMU maka trend rugi yang di derita PLN MMU masih berlanjut meningkat.

Peningkatan rugi usaha pada PLN MMU secara otomatis akan berimbas secara proporsional dengan Indikator keuangan ROI (Return On Invesment) dan Rasio EBITDA Margin.

Beberapa indikator keuangan yang menunjukan kondisi kesehatan keuangan pada PLN Wilayah

Maluku \& Maluku Utara selama tahun 2015 s.d 2017 adalah sebagai berikut :

a. Harga Jual Rata-Rata $(\mathrm{Rp} / \mathrm{kWh})$

b. Umu Piutang

c. Rasio Perputaran Material

d. Rasio Perputaran Aktiva

e. Rasio Subsidi

f. Rasio Operasi

\section{KESIMPULAN}

Berdasarkan hasil penelitian, maka kesimpulan dalam penelitiain yaitu :

1. Tingkat produktivitas tenaga kerja perusahaan mengalami kenaikan yang relative lebih tinggi dibandingkan peningkatan produktivitas tenaga kerja perusahaan sebelum penerapan Malcolm Baldrige.

2. Penerapan aplikasi Malcolm Baldrige pada PT. PLN (Persero) Wilayah Maluku dan Maluku Utara sangat baik dalam melakukan pengukuran, analisa dan perbaikan kinerja organisasi.

\section{DAFTAR PUSTAKA}

Abdullah, Ma'ruf. (2014)., Manajemen dan Evaluasi Kinerja Karyawan. Yogyakarta: Aswaja Pressindo. Akbar,Nicky.2011. Pengukuran Kinerja Perusahaan Jasa dengan Pendekatan Balanced Scorecard pada PT. Pandu Siwi Sentosa. Skripsi tidak diterbitkan. Bogor: Institut Pertanian Bogor.

Akdon.(2007)., Strategic Management for Educational Management. Bandung: Alfabeta.

Anthony, Robert, dan Vijar Govindarajan.(2005)., Management Control System. Jakarta: Salemba Empat.

Armstrong, Michael dan Angela Baron. (1998)., Performance Management. London: Institute of Personnel and Development.

Ayuningtyas,Sumarni, Bachtiar. (2005)., Penilaian Mutu Rumah Sakit Tugu Ibu dengan The Malcolm Baldrige Quality Award tahun 2005. JMPK , (Online), Vol. $08 . \quad$ No. 4. (http://jurnal.ugm.ac.id/jmpk/article/viewFile/2937/2656/, diakses 04 maret 2015).

Azhar,Al.(2009). Pengukuran Kinerja melalui Just In Time dan Balance Scorecard. Pekbls Jurnal, (online), Vol.1, No.1 (http://download.portalgaruda.org, diakses 20 April 2015).

Bone,Hariman, dan Mahfuz Solihin. (2012)., Pengaruh Perspektif dan Jenis Ukuran dalam Balanced Scorecard Terhadap Evaluasi Kinerja. SNA 15 Banjarmasin (http://asp.trunojoyo.ac.id, diakses 22 Februari 2017).

Blazey,L.Mark. (2009)., Insights to Performance Excellence 2009-2010. United States of America: American society for quality. 
